\title{
Linguistic Diversity and European Democracy
}

Kjær, Anne Lise; Adamo, Silvia

Publication date:

2011

Document version

Publisher's PDF, also known as Version of record

Citation for published version (APA):

Kjær, A. L., \& Adamo, S. (Eds.) (2011). Linguistic Diversity and European Democracy. Ashgate. https://www.routledge.com/products/9781409408604 


\title{
(C) Copyrighted Material \\ Chapter 1 \\ Linguistic Diversity and European Democracy: Introduction and Overview
}

\author{
Anne Lise Kjær and Silvia Adamo
}

\section{Introduction}

Theorists of political science and sociology do not often ask themselves how deliberative democracy should function in polities that are made up of many linguistic groups and seem to forget the impact that linguistic diversity may have on political communication and mutual understanding across languages. If language is considered at all in studies of democracy, it is treated as a companion to culture, as the essential core of national or minority group identity. Likewise, although lawyers spend a great deal of time carefully studying the language of statutes and court decisions, they do not seem to be sensitive to the issue of language when reflecting on norms of deliberative democracy, ${ }^{1}$ or they tend to address the issue only from the point of view of human rights and constitutional guarantees of the right to speak one's own language. Similarly, lawyers interpreting European Union law think of "the language" of EU legislation and speak of "the wording of the text" without taking into account that language and wording within the framework of the EU always imply a multiplicity of 23 official languages. In other words, multilingualism and linguistic diversity are matters that are not commonly analysed or even thought of as matters of relevance in mainstream political, sociological and legal theories of EU law and democracy.

At the same time, much relevant knowledge about language, cognition and communication remains within the confines of the academic disciplines of linguistics and communication studies and is seldom utilized in the related disciplines of law, sociology and political science. What language is, how it functions in real-life interactions, how people understand languages, and how they communicate across linguistic barriers are underexplored questions that ought to attract more attention in legal, sociological and political studies of EU constitutionalism and European democracy.

The ambition of this book is to fill the gap that exists among the disciplines of linguistics, law, political and social science in the study of polity-building in Europe. The goal is to explore, from a cross-disciplinary perspective, the

1 Addis (2007: 101-2). 
role that linguistic diversity plays in European democracy at both the European and national levels and to shed new light on the issue by employing legal and political theories of law and democracy along with linguistic theories of language use and cognition. Linguistic diversity can be examined from many different perspectives that are usually mutually exclusive or competing. As such, multilingualism can be considered as: a democratic value to be protected, a fundamental right of minority groups, an obstacle to deliberative democracy and a hindrance to legal certainty and the possibility of uniform law, a cultural asset of Europe to be promoted and protected, a competitive advantage of businesses on the market and a prerequisite for the free movement of EU citizens. The aim of this book is to combine these and other perspectives, thereby addressing what we see as the fundamental characteristic of European language laws and language policy, namely the inherent tensions and contradictions. In order to achieve our goal, we have invited researchers representing a variety of disciplines that do not usually collaborate to contribute to the book, viz. EU law and legal theory, political science, sociology, sociolinguistics and cognitive linguistics.

\section{Democracy, Language and Deliberative Communication}

The conference from which the chapters of this book are derived was held just before the 2009 elections to the European Parliament. The research themes of the book are particularly interesting when seen against the backdrop of this European event, as the elections clearly illustrated the inherent paradoxes of European language policy and the language regime of the EU institutions, ${ }^{2}$ as also evidenced in the official EU motto "united in diversity". 3

At that time, 736 members of the European Parliament were to be elected by 375 million potential voters in the 27 Member States. There were no common campaigns across borders, no transnational political communication among citizens of different Member States and no common European parties addressing themselves to voters by means of common European media. When the Parliament facilitated Internet-based communication with and among the electorate, 10,000 voters responded to an online poll conducted at the end of May, and the majority view was that "politicians and media weren't giving the June European elections the attention they deserve". However, in spite of the common European democratic ambition thus pursued by the Parliament, the language paradox became apparent in statements like the following on the Parliament's website: ${ }^{4}$

2 As regards other paradoxes of European law and language, see Kjær (2008).

3 Available at: http://europa.eu/abc/symbols/motto/index_en.htm.

4 Available at: http://www.europarl.europa.eu/sides/getDoc.do?pubRef=-//EP// TEXT+IM-PRESS+20090511STO55546+0+DOC+XML+V0//EN [accessed: August 2010]. 
The Parliament is running an intense campaign on the web, talking about the elections and why it matters that people vote for the Europe they want. There is our special interactive website on the elections in 22 languages.

On the one hand, communication in 22 languages (the 23 official languages minus Irish) is respectful of Europe's linguistic diversity and the language rights of EU citizens. On the other hand, the statement illustrates the top-down communication of the Parliament with EU citizens, who for their part are divided by their different languages and therefore dependent on the Parliament, their national politicians and the press to inform them about the elections and to debate on their behalf.

But the language problem is also evidenced in a new democratic tool introduced by the Lisbon Treaty, namely the European Citizens' Initiative (ECI), which invites EU citizens to participate more directly in the democratic processes of the EU. If a minimum of one million citizens across at least one-third of the Member States (currently nine out of 27) support such an initiative, they have the right to bring forward legislative proposals that the European Commission has to examine within a time limit of four months. In the Commission's "Proposal for a regulation of the European Parliament and of the Council on the citizens' initiative", 5 the objective and rationale of this democratic innovation is described as follows:

This new provision is a significant step forward in the democratic life of the Union. It provides a singular opportunity to bring the Union closer to the citizens and to foster greater cross-border debate about EU policy issues, by bringing citizens from a range of countries together in supporting one specific issue.

The ambition to foster a greater cross-border debate about EU policy lies at the very heart of the attempt to create a European participatory democracy. At the same time, however, it exhibits the weakness of a democracy consisting of different peoples that do not share a language. According to the latest statistical report on Europeans and their languages, ${ }^{6}$ only about half of Europeans are able to speak a language other than their own. This implies that in all probability the ECI will be utilized primarily by European elites who speak English and other widely used European languages with such fluency that they can engage in a cross-border debate with other citizens or by NGOs that have sufficient financial and human resources at their disposal to work across Member State borders.

However, the ECI also exposes the above mentioned inherent contradictions of the European democratic vision of creating unity in diversity: Linguistic diversity is supported and protected at the EU level, yet in real-life interactions

5 COM (2010) 119 final, published on 31 March 2010.

6 European Commission. 2006. "Europeans and their Languages", Special Eurobarometer 243, February. 
among Europeans, linguistic diversity soon meets its limits. ${ }^{7}$ In this respect, it is interesting to note that Article 4(1) of the proposal for a regulation on the citizens' initiative stipulates that the organizer of an ECI must register the initiative with the Commission, providing information on the subject, objectives and background of the initiative "in one of the official languages of the Union".

In other words, the goal of "bringing Europeans from a range of countries together", as the Commission proposal has it, tends to put the citizens' right to speak their own language at risk. They have to agree on one common registration language, which will in all probability be English.

\section{Linguistic Diversity as a Fundamental European Value}

At the time of writing (August 2010), the EU has 27 Member States and 23 official and working languages. Moreover, depending on how languages are defined and what inclusion criteria are used, more than 100 regional and minority languages are spoken in Europe. ${ }^{8}$

So, the obvious questions are why the EU - in the interests of European democracy - does not agree on one common language ${ }^{9}$ and why it does not recommend and support foreign-language teaching that would prepare Europeans to be highly competent in that common language in addition to their mother tongues? Why not use a "mother tongue plus one common European language" strategy instead of the "mother tongue plus two foreign languages" that is currently stated to be the aim in Commission policy instruments? ${ }^{10}$

The answer to these questions is probably multifaceted. One simple reason is that the language spoken by approximately 38 per cent of EU citizens, besides their mother tongues, is so-called global English, ${ }^{11}$ and speakers of the other European "majority" languages - especially French, German and Spanish - object to the anglicization of Europe. ${ }^{12}$ Another reason is that the protection of linguistic diversity and the protection of language rights are regarded as

7 See, similarly, Kraus in this volume.

8 In 1992, the Commission initiated a study on minority language groups in the European Union. While the so-called Euromosaic I study listed 48 linguistic minority groups living in the 12 Member States at that time, a survey conducted after the 2004 enlargement counted approximately 90 minority groups in the new Member States, differentiated on the basis of language.

9 For a more in-depth discussion of this question, see Wright in this volume.

10 See Gravier and Lundquist in this volume.

11 European Commission. 2006. "Europeans and their Languages", February 2006.

12 Consider, e.g., "Die Mannheim-Florentiner Empfehlungen zur Förderung der europäischen Hochsprachen" (The Mannheim-Florence Recommendations for Promoting European Standard (or National) Languages) formulated by the language institutions of some EU Member States, notably Germany and Italy. See also Phillipson in this volume. 
fundamental European values and are thus essential to the very concept of a European substantive democracy. ${ }^{13}$

The idea of linguistic diversity as a specific European value that distinguishes Europe from other parts of the world is evidenced in several talks given by the former European Commissioner for Multilingualism, Leonard Orban, who was commissioner from 1 January 2007, when Romania became a member of the Union, until the new Commission was set up after the entry into force of the Lisbon Treaty on 1 December 2009. At a conference on multilingualism in Romania on 15 May 2009, he rather grandiosely summed up the underlying principles of European language policy as follows:

Today we live in a globalized world and Europe is building an ever closer Union. While, on a global level, some "big" languages tend to dominate the scene, Europe is not a melting pot where differences are blotted out. Europe is a common home where diversity is celebrated, and where our many mother tongues are or should be a source of wealth and a bridge to greater solidarity and mutual understanding. ${ }^{14}$

The paradox of the commissioner's speech is, of course, that the "many mother tongues" may be seen as a source of greater cultural wealth and a catalyst for greater solidarity, but at the same time they impede mutual understanding and almost invite being bridged - by a common language. On the one hand, linguistic diversity is a symbol of European democracy, but on the other hand, linguistic diversity complicates political dialogue and the exchange of ideas in "a community that cannot communicate". ${ }^{15}$ Thus, linguistic diversity runs counter to the ideals of the "four freedoms" of the internal market, but it is a fundamental European value protected by the EU treaties and the Charter of Fundamental Rights of the European Union and promoted by several Community initiatives. In a market where goods, capital, services and persons are encouraged and expected to move freely, the diversity of languages is, in fact, a hindrance to such movement. However, it is politically and legally impossible to acknowledge this point. The pragmatic solution is to make linguistic diversity a commodity, a valuable cultural good and a political instrument in the hands of Europe's minorities, by means of which they can circumvent the national level and strive for more European integration. This is the policy that is actually pursued by the Commission. In the latest policy initiatives in the field

13 Article 22 of the EU's Charter of Fundamental Rights requires the EU to respect linguistic diversity and Article 21 prohibits discrimination based on language. Article 2 of the Treaty on European Union lists the common values of the EU Member States, including pluralism, non-discrimination and equality.

14 Available at: http://ec.europa.eu/commission_barroso/orban/news/docs/speeches /090515_discurs_Cluj/Discurs_Cluj_EN.pdf [accessed: May 2010].

15 Terminology borrowed from Sue Wright (2000). 
of language and multilingualism, the Commission stresses the importance of multilingualism and learning languages, not only for European culture, but also for European business and creativity. ${ }^{16}$

\section{Linguistic Diversity and EU Law}

The inherent paradox expressed in the motto "united in diversity" also affects the legal regime of the EU. ${ }^{17} \mathrm{EU}$ legislation with general application throughout the Community must be published in all 23 official languages. On the face of it, this rule seems reasonable as the EU passes laws that are directly binding on individuals and companies in the Member States. But the publication in all 23 languages is not primarily for information purposes, enabling EU citizens and their legal advisors to read EU legislation in their own languages. It is first and foremost a matter of equal treatment of small and large Member States; consequently all 23 language versions have equal authenticity, even if this makes the interpretation of EU law extremely complicated.

As stated by Greece in the case Kik v OHIM:18 "Multilingualism is an indispensable component of the effective operation of the rule of law in the Community legal order, since many rules of primary and secondary law have direct application in the national legal systems of the Member States". In a similar vein, in its judgment in the famous CILFIT case, ${ }^{19}$ the court held:

It must be borne in mind that Community legislation is drafted in several languages and that the different language versions are all equally authentic. An interpretation of a provision of Community law thus involves a comparison of the different language versions. ${ }^{20}$

16 Leonard Orban, Commissioner responsible for multilingualism until December 2009, set up a Business Forum on Multilingualism in November 2007. The aim of the group was to identify ways to increase the multilingual capacities of companies to help them enter new markets, and to strengthen language skills of individuals so as to improve their employment prospects. The Business Forum presented its report, "Languages Mean Business", to the Commission in July 2008. See also the ELAN report: "Effects on the European Union Economy of Shortages of Foreign Language Skills in Enterprise" of December 2006. Similarly, the Commission recently commissioned a study on multilingualism and creativity; the research group published their report, "Study on the Contribution of Multilingualism to Creativity", in July 2009.

17 The legal consequences of multilingualism are subject to thorough discussions in the contributions of Bengoetxea, Bobek and Derlén in this volume.

18 Judgment of the Court in Case C-361/01 P, Christina Kik v Office for Harmonisation in the Internal Market [2003] ECR I-8283. The Hellenic Republic, intervened at first instance in support of the appellant.

19 Judgment of the Court in Case 283/81, Srl CILFIT and Lanificio di Gavardo SpA $v$ Ministry of Health [1982] ECR 3415.

20 Paragraph 18 in the CILFIT case. 
Paradoxically, it follows that the meaning of EU provisions cannot be derived from any one of the official languages. Thus, in legal terms, the equality of the languages goes so far as to make the language versions of Community laws interdependent. ${ }^{21}$ Hence, EU citizens cannot purely rely on their own languages when they want to know what EU law says on a particular issue. In principle, EU citizens must know the law in each and every official language because the meaning of the law is anchored not in one single language version, but in all the language versions taken together.

Despite the 23 official languages being of ostensibly equal standing, the wording of Community law will invariably differ from one language text to another as natural languages cannot by their nature be absolute copies of each other. Hence, European multilingualism can in some cases be a source of legal miscommunication, misinterpretation, incoherent and divergent texts and, ultimately, an obstacle to achieving what lies at the very core of the rule of law, namely legal certainty.

Moreover, as regards the inherent contradiction between the concepts of unity and diversity, the European Court of Justice long ago ruled that unity, that is, the uniform interpretation and application of EU law in the Member States, is so important that the diversity of interpretation that would arise if EU citizens were allowed to apply their own language versions should be avoided:

The different language versions of a Community text must be given a uniform interpretation and hence in the case of divergence between the versions, the provision in question must be interpreted with reference to the purpose and general scheme of the rules of which it forms a part. ${ }^{22}$

Moreover, even if multilingualism is an "indispensable component of the effective operation of the rule of law in the Community legal order", the European Court of Justice ruled in the Kik case that the references in the Treaty to the use of languages in the European Union:

cannot be regarded as evidencing a general principle of Community law that confers a right on every citizen to have a version of anything that might affect his interests drawn up in his language in all circumstances. ${ }^{23}$

What is it about language that seems to make things so complicated?

\section{Linguistic Diversity and Language Rights}

To most researchers other than linguists, "language", in the singular at least, is a trivial subject, which is not worth studying when one wants to discuss matters

21 Van Calster (1998).

22 Judgment of the Court in Case 30/77, Régina v Pierre Bouchereau [1977] ECR 1999.

23 Paragraph 82 in the Kik case. 
relating to law, society and politics. Language as a discipline probably reminds people of language teachers and lessons at school: Put the comma in the proper place, spell correctly and beware of dangling participles and split infinitives!

At the same time there seems to be widespread agreement across the various research communities that language in the plural ("languages") and multilingualism are not trivial matters. On the contrary, the protection of linguistic diversity and the struggle for language rights are acknowledged as battlefields for a variety of interests: political, legal and cultural. In other words, languages in the plural are much more fascinating than the school teacher's narrow interest in the nitty-gritty details of "language".

But what can possibly be the connection between the "boring" language lessons at school and the much more inspiring subjects of language rights and language diversity in European law and politics?

To answer the question, a comparison between language and music is instructive. Some time ago, the well-known and respected Danish cellist Morten Zeuthen was interviewed on Danish national radio. He described his love for music and his fascination with his own instrument, the cello. He also touched on his teaching at the Royal Danish Academy of Music: position fingers precisely, hold the bow correctly and read the notes! These are some of the technical instructions he gives his students. The point is that such tasks have nothing to do with the music that is made once the students have learned to place their fingers correctly, hold the bow and read the notes. Furthermore, they have nothing to do with the students' love of music and their instruments.

Now imagine that a cello player was forced to shift to another instrument. The following instructions might be given: "In this orchestra we all play the violin, and it is not possible for you to play the cello. You are free to do so at home, but when you are with us, you have to play the violin". Imagine that all musicians other than violin players were told the same thing, regardless of whether their expertise was in playing the flute, the viola, the horn, the piano or another instrument. How would the musicians react? They would probably fight for their right to play their own instruments.

The love of one's own first language may be compared with the love of one's instrument - and is probably felt most strongly when one's right to speak that language is prohibited. A particular language is not just an arbitrary instrument of communication as far as native speakers are concerned. It is the reservoir of their memories, the reflection of their identity and the language that they speak when they want to be precise, intimate or poetic. Therefore, being forced to speak another language, by others or by circumstances, is not a trivial matter easily dealt with and accepted. ${ }^{24}$

24 In her contribution to this book, Dagmar Richter presents the Swiss solutions to the conflicting and contradictory problems caused by multilingualism at local, regional and national levels. 
The comparison between language and music has its limits, however. It is, of course, possible for musicians to meet and play different instruments - in fact, it is not only possible, it is desirable; that is how orchestral pieces are played. When it comes to languages, however, they are like the secret codes invented in the schoolyard: codes that are only understood by those who know the rules and the specific vocabulary.

Thus, the contradiction of being "united in diversity" emerges once again. Languages are exclusive, and they exclude. Even if the possibility for speakers of a minority language to speak their own language should be protected, representing a fundamental constitutional right in democratic societies, supported at both national and European level, ${ }^{25}$ minorities would be culturally, socially and politically isolated if they were unable to speak the language of the majority. Therefore, one might conclude that language rights should be concerned not only with the protection of linguistic diversity and the right to speak one's own language, but also with the right to learn the language that enables one to be among those who exercise power, or, less ambitiously, to understand the linguistic code of those in power. ${ }^{26}$

\section{The Language of European Democracy}

The diversity of languages means richness, but it also means difference, divergence and even mutual isolation. If one wants to communicate despite the diversity, one either has to insert mediators - translators and interpreters - who can bridge the language gap or communicate in a common language, that is, learn the handful of languages necessary to communicate with other Europeans.

What is the language of democracy? This question is one posed by the political philosopher Will Kymlicka, who answers the question by maintaining that the language of democracy is the vernacular: the mother tongue. ${ }^{27}$ But what is then the language of European democracy? Jürgen Habermas has suggested that English should be the common language of Europe. ${ }^{28}$ Clearly, language diversity seems to represent a major hindrance to Europe-wide democracy - at least if we endorse a conception of democracy under which the political participation of the general population is required.

The linguistic paradox of European democracy is, however, that if the EU were to enact a one-language policy, which might be sensible in terms of developing a European public sphere, it would at the same time contravene what lies at the very heart of that democracy, namely non-discrimination and respect for difference and diversity.

25 This is the subject matter of de Witte's contribution in this volume.

26 For a discussion of the very notion of "language", see Normann Jørgensen in this volume.

27 Kymlicka (2001).

28 Habermas (1998). 
Most EU Member States seem to endorse the view that diversity is valuable only if they are in charge of that diversity, defining its meaning and limits. Thus, minority language rights are protected and diversity celebrated only with respect to languages with a long historical presence in Europe. The increasing and widespread presence of non-European immigrant languages is not protected by language laws. On the contrary, immigrants are generally obliged to learn the national languages of their new countries, and in several European countries, language tests requiring high-level linguistic competence have been introduced during the past few decades. ${ }^{29}$ Paradoxically, a command of the national language is not a requirement that high-skilled workers and academics have to meet. They are generally free to use the global common language, namely English.

It does seem as if "united in diversity" is a normative vision of Europe with limited descriptive value. In real life, diversity is supported and upheld only if it is practicable and compatible with values and goals that are considered more important: the efficient working of the EU institutions, the functioning of the free market, continued legal and political integration and European participatory democracy.

\section{Overview of the Book}

The book is opened by Peter A. Kraus, who gives us the first indications of how to explore the connections between the issues of European democracy and linguistic diversity. Language has played a prominent role in the construction of modern nation states but also in the consolidation of an understanding of democracy based on "integrated communicative spaces", where the creation of a public sphere communicated by means of a common language makes possible the monitoring and thus the legitimation of political decision-making. This model of political integration via linguistic standardization encounters clear difficulties when translated to EU level. Kraus challenges the understanding of democracy as "democracy in one language", which in a certain way obstructs the development of multilingual democratic practices. At the same time, he indicates the contradictions pervading cultural and linguistic diversity in the EU. One of the dilemmas is that communication in a multilingual supranational setting involves the use of either a common language or interpretation, while another obstacle is the nation state-based conception of "minority" when linguistic rights are defined. The process of EU integration aims to preserve European citizens' cultural and linguistic diversity, but the initiatives and legal instruments adopted so far in this field have lacked normative impact. Thus Kraus makes us reflect on the necessity,

29 See, for example, the special issue of the International Journal on Multicultural Societies "Citizenship Tests in a Post-National Era" (guest editor: Sue Wright, 2008), and in the same issue the analysis of the Danish legal setup as regards linguistic requirements for applicants for citizenship presented in Adamo (2008). 
in order actively to defend the EU's cultural and linguistic diversity, to develop other types of enforcement mechanisms (including social and cultural); these may have to be adapted from those that fostered the "dynamics of democratization" in EU Member States.

Sue Wright opens the discussion on European democracy, asking the fundamental question: What does democracy mean to Europeans? As the European polity has not yet fully evolved, the elements which characterize democracy in a nation state cannot yet apply to the EU, where the concept of democracy does not refer to any single overarching concept. Wright considers in particular the element of debate as an essential democratic practice and investigates whether there are any lessons we can draw from the democratic experiences of the past, from the elite democracy of ancient Greece to the adoption of the French and American Constitutions in the eighteenth century. From this perspective, Wright notes that the current debate in the European public sphere is clearly still underdeveloped as citizens try to form opinions often based only on information gathered from national news. She reminds us that public participation and a common language can foster the conditions for a truly democratic debate on a common European constitution, although, at the end of the day, it is the powerful and symbolic value of their national constitution that is the key to democracy in the eyes of most of the electorate.

Robert Phillipson's contribution focuses on the more problematic aspects of multilingualism in Europe. He suggests that the primary role acquired by English in a variety of administrative and working contexts in the EU institutions can result in asymmetrical communication and uneven dissemination of information and documents. Phillipson reviews the obstacles that lie ahead when establishing equity of treatment of languages in the EU, and stresses the need to clarify what "functions, contexts, and users of particular languages" are at stake as the different uses can entail different requirements under a policy of multilingualism. Phillipson's view on legal and political initiatives so far taken at EU and Member State level is that they have not succeeded in directing language policy in a focused way. A shift to a true multilingual infrastructure would mean the need to address and cope with the issue of the predominance of one language. As the issue of language is an integral part of European political integration, Phillipson argues that true multilingualism can only be achieved if it is actively discussed and formulated on an informed basis, not left to market forces, and if professional expertise and scholarly research on linguistic matters assume a more prominent role in the decision-making process than they have done hitherto.

The chapter by Magali Gravier and Lita Lundquist provides an overview of laws and policies governing multilingualism in the EU. They discuss how the issue of multilingualism is closely associated with issues of (passive and active) representative democracy and also with a cognitive-cultural dimension. The value per se of supporting citizens learning multiple languages is complemented by the cultural value of encouraging mutual understanding among EU citizens. Multilingualism is promoted via the recruitment rules for EU civil servants to 
ensure that EU institutions are multilingual at staff level. Moreover, translation and interpretation services have the practical task of making the great flow of documents intelligible for all parties involved and for making communication in meetings possible. In line with the latest initiative by the EU Commission to promote trilingualism among EU citizens, Gravier and Lundquist propose an alternative approach. As studies in linguistics have highlighted, it is possible intuitively to comprehend a foreign language belonging to the same language family; exploiting the mutual structures and common features of languages would consequently promote foreign language teaching and learning. Gravier and Lundquist argue in favour of introducing a system of foreign language teaching that supports the acquisition of a plurality of languages, which should in their view be endorsed not only at the EU institutional level, but ideally also by via Member States' initiatives.

The chapter by Joxerramon Bengoetxea takes a special look at the multilingual challenges posed by the work of the European Court of Justice. Drawing parallels to the stunning new architecture of the Court, Bengoetxea argues that its legal reasoning does not always live up to its own, case law-based commitment to multilingualism and to the duty to compare the equally authentic official language versions of EU legislation. Bengoetxea's review of how multilingual judicial reasoning is carried out in practice makes clear the importance of linguistic matters in the functioning of the Court. EU law is inherently multilingual, reflecting the reality of linguistic diversity in Europe, and the product of legal practices carried out in a number of languages, assisted by the vital work of the translation services. The Court is forced to work in a common language, as it is unrealistic to expect the judges and advocates general to master all 23 official languages. Also, the authenticity of the final judgment is in practice often tied up with the language of the case, while the judgments are published in all official languages. Although the differences in legal cultures affect how the Court functions, Bengoetxea argues that the legal reasoning is in practice usually monolingual and that the cases in which a comparison of language versions is used as a means of interpretation are relatively few.

Michal Bobek offers an analysis of the practical and legal consequences of the multilingual regime of EU law at the national level, when national authorities (courts and administrative authorities) apply EU law. The chapter focuses first on the duty to publish EU legislation in all official languages and, in the light of the landmark decision in the Skoma-Lux case, ${ }^{30}$ discusses the problem of national enforcement of unpublished EU legislation in the new Member States. Second, he examines the use of corrigenda that rectify mistakes in particular language versions. Bobek shows that such corrections are not always of a purely formal nature: in some cases they change the legal meaning, thus giving rise to doubts concerning the interpretation of the legislative act and the legal status of the corrigendum. Finally, Bobek presents the jurisprudence of the European Court

30 Case C-161/06, Skoma-Lux sro v Celní ředitelství Olomouc [2007] ECR I-10841. 
of Justice in relation to divergent language versions and the duty to compare the texts in all official languages. As the burden of comparing the language versions falls on the national authorities, the author sees as a likely outcome the emergence of "language clusters". In other words, the comparison of versions in similar languages can provide a viable solution to prevent linguistic disunity caused by divergent national interpretations and at the same time allows interpreters at national levels to rely on the wording in their own text version, read in the light of related languages.

The chapter by Mattias Derlén reflects on how multilingualism per se is not the problem many assume it to be when initially approaching the subject; rather it is that "the conflicting and unclear directions concerning the relationship between multilingualism and the interpretation of Union law emanating from the European Court of Justice" mean that multilingualism tends to become problematic when it is tied up with the interpretation of EU law. The Court has gone so far as to require that all language versions have to be consulted, thereby underlining the fundamental importance of multilingual interpretation. Derlén notes that this practice has not paved the way for genuine multilingual interpretation on the part of the national courts, nor has any single method been employed by the Court to decide in cases of a divergence of meanings between language versions. He concludes that multilingualism is, in fact, an asset of EU law, as multilingual interpretation may help interpreters establish the correct meaning of EU legislation. However, the obligation to compare all 23 language versions makes genuine multilingual interpretation impossible for practical reasons. Therefore, the author suggests what he calls "limited multilingualism". As he puts it:

By using English and French side by side with the national language version, we would encourage more multilingual interpretation and aid national courts in the difficult task of applying EU law.

Bruno de Witte explores the topic of language rights. Language rights are defined as the fundamental right to speak the language of one's choice: a right expressed in some national constitutions and increasingly in EU law as well. In the opinion of de Witte, language rights gain depth and substance through the link with other rights such as freedom of expression, equality and non-discrimination and the right to education. In this vein, de Witte argues that the protection of linguistic rights is improved when such rights are seen through the prism of general fundamental rights, especially because, when conceived as such, they compel governments to justify any denial of a language-related claim. De Witte explores these points by looking at the development of language rights in national law during the last two decades and also analyses the emergence of an EU-wide supranational standard of protection. He discusses the respective roles of domestic and EU developments and their interaction, in the evolution of language law, in a selected number of Western European countries: the United Kingdom, Italy and Belgium. In his concluding remarks, de Witte argues that the protection of minority language rights in Europe 
has evolved with limited recourse to litigation before the courts: mostly it has been put forward and promoted by way of political mobilization.

Dagmar Richter introduces us to the legal setup for the protection of linguistic diversity in Switzerland. With the help of a "linguistic map", Richter takes us on a journey through a country where German, French, Italian and Romansh are recognized as national languages and where federal and cantonal institutions are obliged to protect the country's linguistic diversity. Richter presents the principles of territoriality and linguistic freedom, as expressed in the Swiss Federal Constitution, which are the core principles of the legal regime in relation to languages in Switzerland. Factual and normative criteria establish the official language(s) of a region's institutions (the territorial principle), taking account of what the author describes as regional "linguistic imprinting". When the regional linguistic imprinting collides with the constitutionally guaranteed individual linguistic freedom, the particular circumstances and the interests at stake are taken into consideration for each individual. Richter suggests that Switzerland's linguistic model could serve as an inspiration for linguistic protection in other countries too. She argues that the linguistic territoriality principle provides a basic structure, counterbalanced by the principle of linguistic freedom, in a caseby-case approach.

Finally, the chapter by J. Normann Jørgensen challenges our preconceived notions of language and introduces us to a (late modern) sociolinguistic approach to language studies. On the basis of empirical analyses of language as it is actually used by people in real-life communication, Normann Jørgensen rejects a conception of language as a static phenomenon linked to a specific culture and nation and claims that languages in this essentialist sense of the word are sociocultural or even ideological constructions. He demonstrates how the common definition of language, which also underlies language laws, does not reflect the everyday use of language. The chapter gives examples of how features from different languages are combined in linguistic interactions among contemporary urban youth in the EU. Such language use is what he calls the polylingualism norm:

Language users employ whatever linguistic features are at their disposal to achieve their communicative aims as best they can, regardless of how well they know the involved languages.

A sociolinguistic perspective on language may help Europeans to rethink how they structure language policies and language laws, and what is actually at stake when we talk about the right to use one's language. The polylingualism norm can be used in this view as a cornerstone in the building of an alternative system for the protection of linguistic rights, tentatively described by Normann Jørgensen as follows: 
In private, as well as in business, people have the right to communicate through language of their choice. In their relationship with public institutions people have the right to expect that the communication be held in language they understand.

\section{References}

Adamo, S. 2008. "Northern Exposure: The New Danish Model of Citizenship Test”. International Journal on Multicultural Societies, 10(1): 10-28.

Addis, A. 2007. "Constitutionalizing Deliberative Democracy in Multilingual Societies". Berkeley Journal of International Law, 25(2): 101-48.

Derlén, M. 2009. Multilingual Interpretation of European Union Law. Aalphen aan den Rijn: Kluwer Law International.

European Commission 2006. "Europeans and their Languages". Eurobarometer 243 (February).

Habermas, J. 1998. "Does Europe Need a Constitution? Response to Dieter Grimm?". In The Inclusion of the Other: Studies in Political Theory, edited by C. Cronin and P. De Greiff. Cambridge, MA: MIT Press, 156-61.

Kjær, A.L. 2008. "Language as Barrier and Carrier of European Legal Integration". In Paradoxes of European Legal Integration, edited by $\mathrm{H}$. Petersen, A.L. Kjær, H. Krunke and M.R. Madsen. Aldershot: Ashgate, 149-56.

Kraus, P.A. 2008. A Union of Diversity: Language, Identity and Polity-Building in Europe. New York: Cambridge University Press.

Kymlicka, W. 2001. Politics in the Vernacular. Oxford: Oxford University Press.

Phillipson, R. 2003. English-only Europe? Challenging Language Policy. London and New York: Routledge.

Van Calster, G. 1998. "The EU's Tower of Babel - The Interpretation by the European Court of Justice of Equally Authentic Text Drafted in More Than One Official Language". In Yearbook of European Law, Vol.17, edited by A. Barav and D. Wyatt. Oxford: Clarendon Press, 363-93.

Wright, S. (ed.). 2008. "Citizenship Tests in a Post-National Era". International Journal on Multicultural Societies, 10(1): 1-9.

Wright, S. 2000. Community and Communication: The Role of Language in Nation Building and European Integration. Clevedon: Multilingual Matters. 
